\title{
Research Paper \\ Identifying and Prioritizing the Needs of Parents of Children with Cerebral Palsy
}

\author{
Motehareh Mohammadnia*1, Abbas Ali Hosseinkhanzadeh ${ }^{2}$ \\ 1. M.A. In Rehabilitation Counseling, Rasht Branch, Islamic Azad University, Rasht, Iran \\ 2. Associate Professor, Department of Psychology, Faculty of Literature and Humanities, University of Guilan, Rasht, Iran
}

Citation: Mohammadnia M, Hosseinkhanzadeh AA. Identifying and prioritizing the needs of parents of children with cerebral palsy. Quarterly Journal of Child Mental Health. 2020; 7(1): 181-192.

http://dx.doi.org/10.29252/jcmh.7.1.16

\begin{tabular}{|c|c|}
\hline A R T I C L E I N F O & A B S T R A C T \\
\hline $\begin{array}{l}\text { Keywords: } \\
\text { Identifying and } \\
\text { prioritizing, } \\
\text { needs of parents, } \\
\text { cerebral palsy }\end{array}$ & $\begin{array}{l}\text { Background and Purpose: Among children with special needs, those with cerebral palsy may } \\
\text { jeopardize the physical and mental health of their parents, because they have special physical } \\
\text { features, need long-term care, and suffer from intellectual disability, learning disorder, aphasia, } \\
\text { auditory/visual impairment, and difficulties in self-help skills. One of the challenges confronted by } \\
\text { the specialists is to render appropriate education and rehabilitation services to parents of children } \\
\text { with cerebral palsy. Therefore, this study was done to identify and prioritize the needs of parents of } \\
\text { children with cerebral palsy. } \\
\text { Method: This study was a descriptive survey. The sample included } 200 \text { parents of children with } \\
\text { cerebral palsy in Guilan province in the academic year } 2017-2018 \text {. They were selected by purposive } \\
\text { method and then completed the researcher-made needs assessment questionnaire for parents of } \\
\text { children with cerebral palsy. Data were analyzed by exploratory and confirmatory factor analysis and } \\
\text { Friedman test. } \\
\text { Results: The findings showed that the needs assessment questionnaire for parents of children with } \\
\text { cerebral palsy included the important dimensions of awareness of the social needs of children, } \\
\text { awareness of the therapeutic needs of children and facilities provided for them, and the need for } \\
\text { knowledge and awareness. Also, among the needs of parents of children with cerebral palsy, concern } \\
\text { about the occupational and marital future of the child (mean score: } 32.46 \text { ), concern about the way the } \\
\text { society may treat the child (mean score: } 31.09 \text { ), and the family efforts and supports to improve the } \\
\text { child's condition (mean score: } 29.46 \text { ) were the most important ones, respectively. } \\
\text { Conclusion: Taking into account the dimensions of the identified needs of parents of children with } \\
\text { cerebral palsy, active participation of the family, awareness of parents about their own needs, and } \\
\text { awareness of the practitioners and authorities about these children and their families are essentially } \\
\text { important for providing the effective education and rehabilitation. }\end{array}$ \\
\hline
\end{tabular}

* Corresponding author: Motehareh Mohammadnia, M.A. In Rehabilitation Counseling, Rasht Branch, Islamic Azad University, Rasht, Iran. E-mail addresses: Mohmmadniya@gmail.com 


\section{شناسايى و اولويتبندى نيازهاى والدين داراى فرزند مبتلا به فلج مغزى}

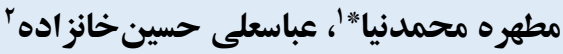

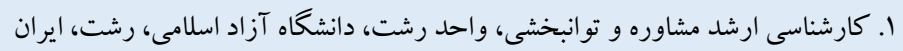

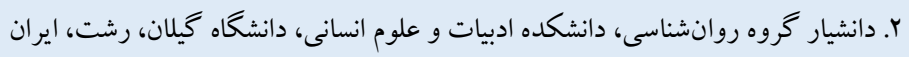

\section{جك}

زمينه و هدف: در ميان افراد با نيازهاى ويزٔه، كود كان مبتلا به فلج مغزى به علت ويز گیىهاى خاص جسمانى و نياز شديد به مراقبت در

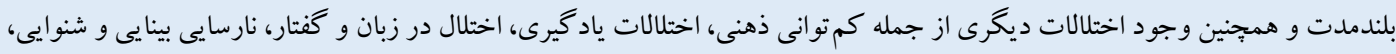

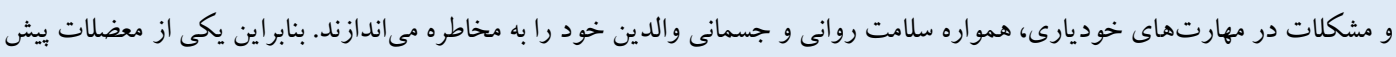

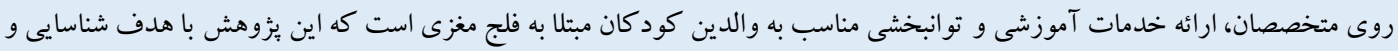
اولويتبندى نيازهاى والدين اين كود كان در حيطه هاى مختلف انجام شد. روش: يثوهش حاضر، توصيفى از نوع زمينهيابى (ييمايشى) است. نمونه مورد مطالعه شامل .r. نفر از والدين داراى فرزند مبتلا به فلج

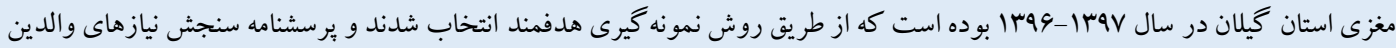

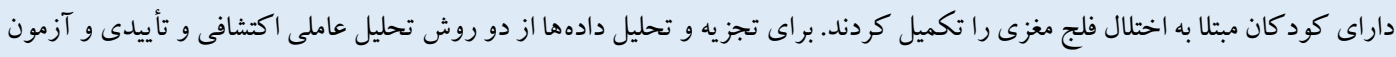
تحليل رتبهاى فريدمن استفاده شد.

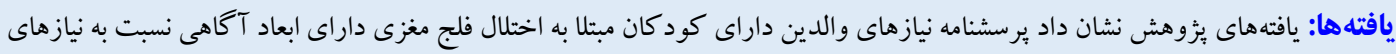

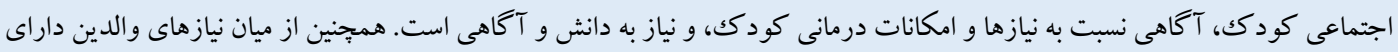

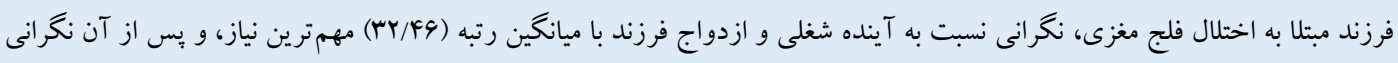

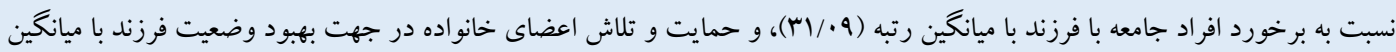

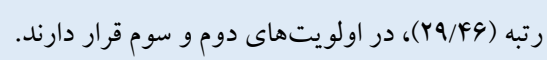

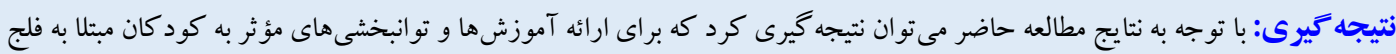

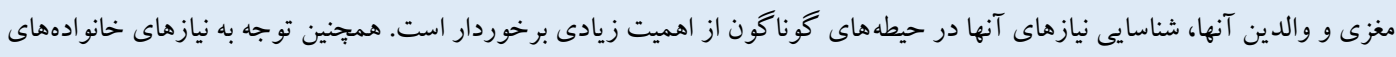

اين كود كان مىتواند باعث مشار كت و فعال بودن هر جه بيشتر والدين در فرايند ار ائه خدمات توسط مسئولان و دستاندر كاران شود.
مشخصات مقاله

كليدوازهها:

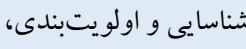
نيازهاى والدين، فلج مغزى

دريافت شده: PV/P/IF

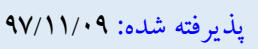

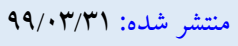

* نويسنده مسئول: مطهره محمدنيا، كارشناسى ارشد مشاوره و توانبخى، واحد رشت، دانشكاه آزاد اسلامى، رشت، ايران.

رايانامه: Mohmmadniya@gmail.com

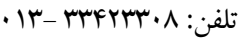


اين گونـه كودكـان علـاوه بر نيـازهاى عمومى براى شــكوفا شـــن

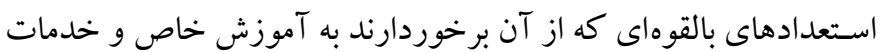

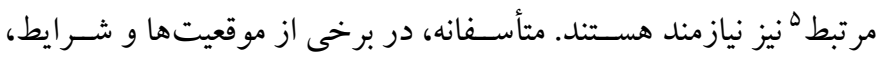

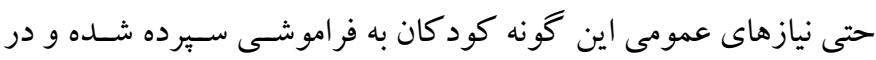
نهايـت تحول آنها در كنش هاى مختلف ارتباطى و آموزشسى با تأخير مو اجه مىشـود (V). هزينهاى بالاى درمانى و رفت و آمد مداوم والدين به مر اكز درمانى و تو انبخشى، آسيب زيادى به ساختار اقتصادى و روانى خانو اده

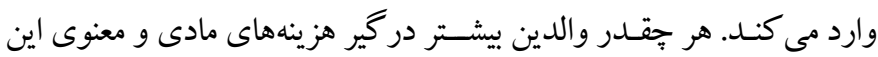
اختلال مىشـوند، به همان نسبت دولتها نيز تحت فشـار هزينهاى ناشى از

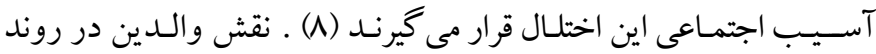

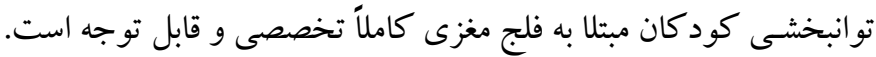

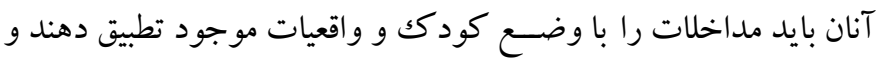
وعـدههـاى آرمانى را از مداخلات واقعى تفكيك كنند (9 و • (1). عوامل

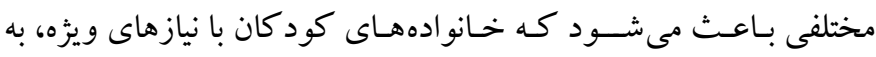
درجات مختلف مشكلات و معضلات مختلفى را تجربه كنند؛ مانند شدت كم توانى يا ناتوانى، نوع ناتوانى، زمان بروز اختلال، و وضسعيت اجتماعى لنى

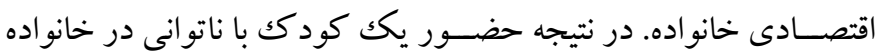
باعث ايجاد تنش ها و مسائل خاصى براى والدين و ساير اعضاى خانو اده

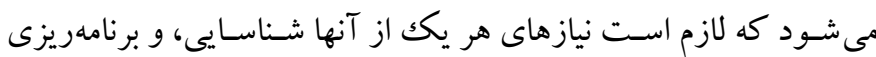
آموزشى و توانبخشى جهت حمايت از آنها، انجام شود. با توجه به ماهيت فلج مغزى و اختلالات همراه با با آن ماند مشكـكلات جسمى، حسى، ذهنى و غيره، نيازهايى در اين افر ادو و والدينشان ايجاد

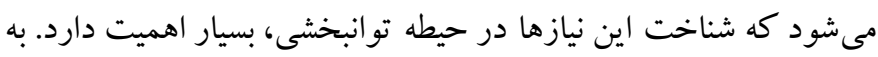

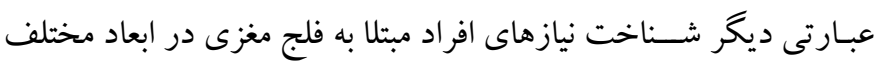

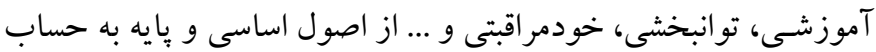
مى آيـد. در اين زمينه ممكن است ارائه دهند كان خدمات توانبخشى

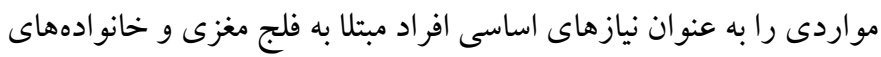

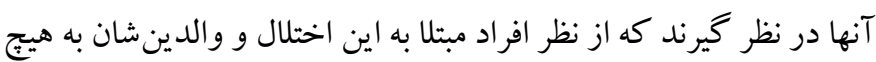

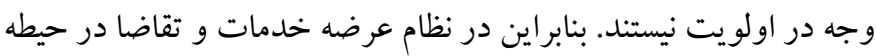
آموزش و توانبخشى، تناسب از بين مىرود و برنامهريزىهاى مربوط بـ بـهـ

4. Exceptional children

5. Special education and related supports مقلdo

دانش و اطلاعات يايه براى بيشـتر فعاليتها و رفتارهاى انسـانى، ضرورى اسـت و والدين در شكل دادن به اين دانش، نقش مهمى ايفا مى كنند؛ به طورى كـه ســـح بـالـاتر اين دانش موجـب تصــميم گيرى و اقـدامات مناسـبـترى مى شـود. والدين در ارائه اين دانش به فرزندان خود و شكل دادن عادت ها و رفتارهاى مربوط به سلامتى، نقش مهمى ايفا مى كنند. در اين بين والدين كود كان با نيازهاى ويزه ' در مقايســه با والدين كود كان بهنجار به اطلاعات و دانش خاصسى نياز دارند تا بتو انند رفتارها و مسـائل خـاص فرزنـد خود را مديريت كنند؛ زيرا كود كان با اختلالات گوناخون ذهنى، جسـمى، و روانى، دار ایى نيازهاى متفاوتى نسبت به ساير كود كان بهنجــار هســتنـل و تنش هـاى زيـادى را براى اعضــاى خـانو اده خود به خصــوص والدين، ايجاد مى كنند ( (1). يكى از اين اختلالات، فلج مغزى اسـت كه معناى لغوى آن، صـدمه به شبكه عصبى مركزى و فلج (فقدان مهـار) عضــلات ارادى اســت. به طور كلى فلج مغزى يك كم توانى (يا

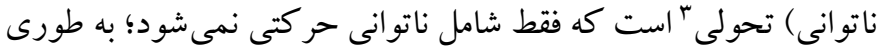
كه تعداد زيادى از كود كان مبتلا به فلج مغزى داراى اختلالهاى حسـى، ادراكى، شناختى، ارتباطى و رفتارى، و مشكلات عضلانى هستند (Y). فلج مغزى به عنوان يكى از شايع ترين اختلالات حر كتى شناخته شده در جهان اسـت كه بر آورد شـيوع آن از ه, ا تا بيش از F كودكك در هر هزار تولد

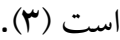

در ميـان كود كان اســثنايى ( (يا كود كان با نيازهاى ويزه)، كود كان مبتلا به فلج مغزى به علت ويز كَى هاى خاص جســمانى و نياز شــديد به مر اقبت در دراز مدت و همجينين دارا بودن اختلالات همبود ديخرى مانند كم توانى ذهنى، اختلـالـات يـاد گيرى، اختلالات ارتباطى (زبان و كفتار)، نارسايى بينايى و شنوايى، و مشكلات در مهارت هاى خودمر اقبتى، همواره ســلامت روانى و جســمانى والدين خود را به مخاطره مى اندازند. علاوه بر آن، اين كودكـان مشــكلـات عـاطفى و حتى اقتصــادى زيادى رادر

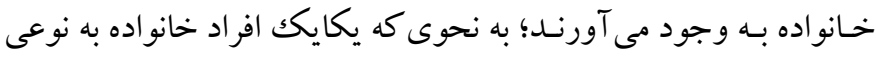
دجار بحرانهاى ناشى از وجود يكك فرد با ناتوانى مىشوند (F- (9).

1. Children with special needs

2. Cerebral palsy

3. Developmental disability (or inability) 
مستقيمى را نشـان داد. همجِنين نتيجه برزوهش براندو، اليويراو مانسـينى (19) نشان داد كه داشتن فرزند مبتلا به فلج مغزى كم توان ذهنى به ميزان

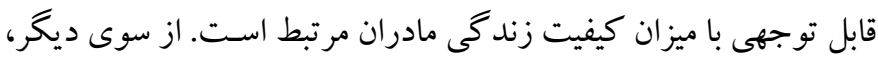

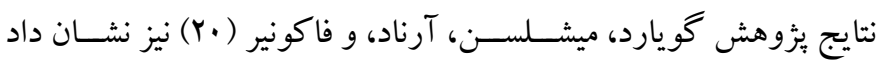
درصســ بسـيارى از والدين نوجوانان مبتلا به فلج مغزى، تنش بالايى در

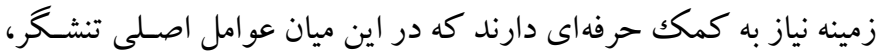
اختلالات حركتى و رفتارى فرزندان بود. همجين نتايج اين مطالعه نشــان

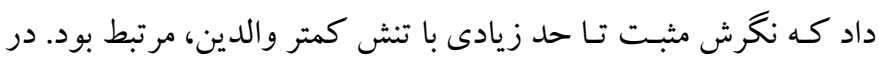

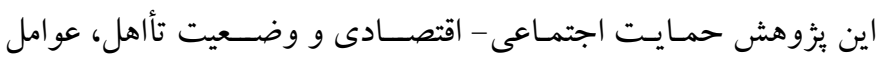

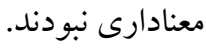
هنگًامى كه يكك كودك در خانوادهاى تشـخيص فلج مغزى دريافت

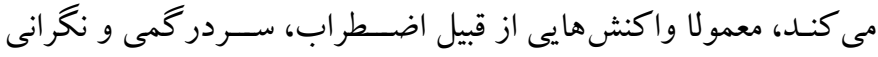

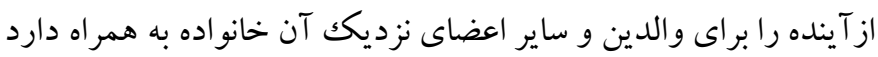

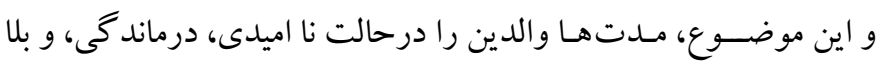
تكليفى قرارمى دهد و در نتيجه به از دست دادن زمان براى تصميم گيرى مهاى

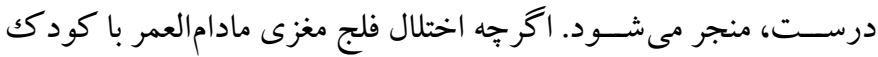
همراه است، ولى راهها و شيوههاى درمانى وآموزشى زيادى بر اى كمكك

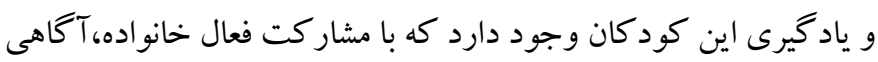
يافتن والدين از نيازهاى خود، و دريافت دانش لازم درباره آموزش هاى

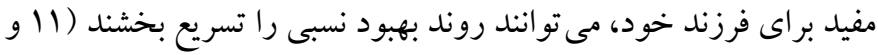

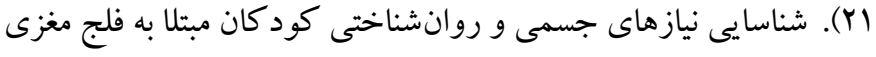

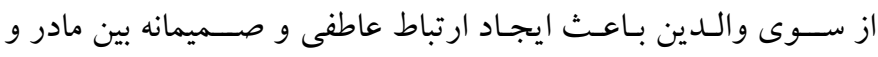

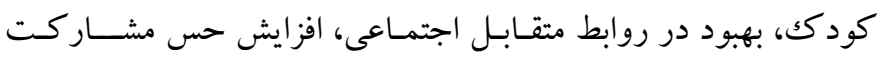

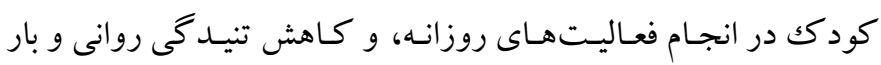
مراقبتى والدين مى شــود. همجنين شــناســايى نيازها مى تواند در فرايند آموزش والـدين داراى كودك مبتلـا بـه فلج مغزى مؤثر باشــــ و باعث

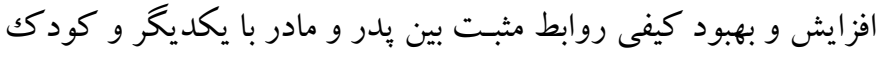
شود (Y)

بـا توجـه بـه اين واقعيت كه كود كك مبتلا به فلج مغزى به بهـاشـــت

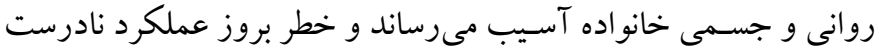
را در خانو اده افزايش مى تدهند، بر اين اســاس هر جه والدين بيشـتر از
ارائه خدمات، دجار مشكل مىشــود و در نهايت منابع، زمان، و نيروى انسانى استفاده شده در اين زمينه، مفيد واقع نمىشوند (11). در اين زمينه سازمان سلامت جهانى' در برنامههاى خود نيازهاى افراد با ناتوانى را به ها مؤلفه تقسيمبندى كرده است كه براى تحقق هر يك سك از

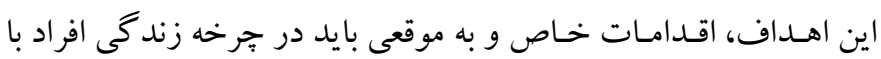

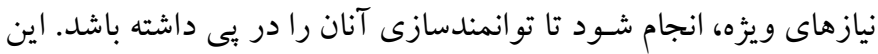

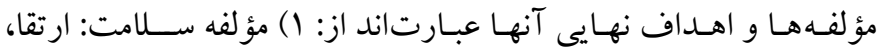

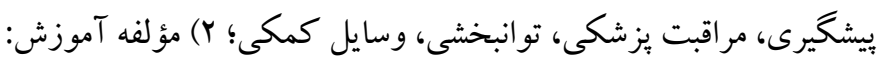

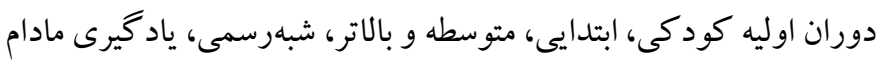
العمر؛ ؟r) مؤلفه معاش: توسـعه مهارت، خود اشـتغالى، اشتغال دستمزدى،

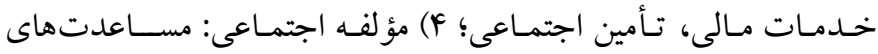

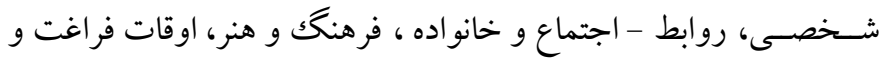

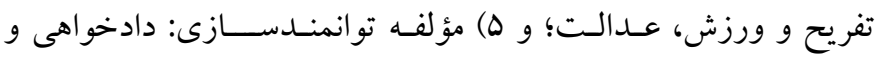

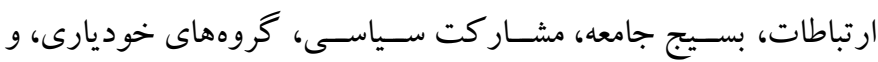
سازمانهاى افر اد با ناتو انى هاى مختلف (IY). مطالعات زيادى درباره مشكلات افراد مبتلا به فلج مغزى، تو انايىهاى

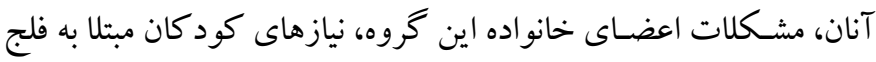
مغزى و والدين آنان، و نظاير آن انجام شده است كه نتايج برخى از آنها

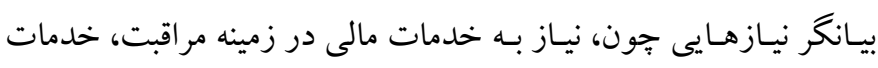
درمانى و يزشكىى، خدمات توانبخشى و تجهيزات مورد نياز (در مجموع مؤلفه ســلامت را شـامل مىشـود)، نيازهاى آموزشسى براى كود كان و

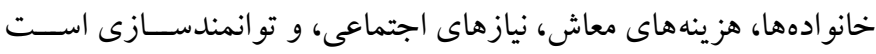

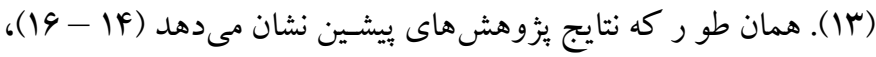

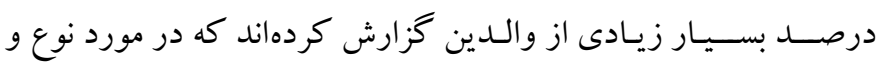

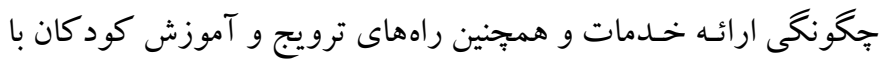

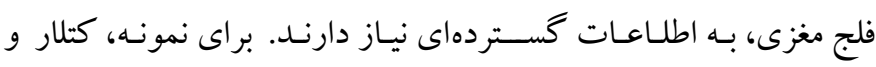

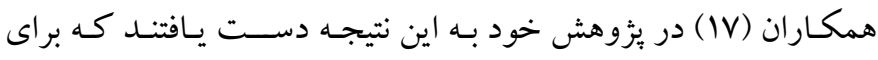

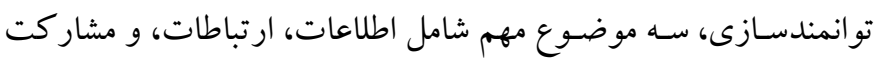
نقش مهمى ايفـا مى كنــ. همبحنين نتايج يثزوهش جو انسـون و همكاران

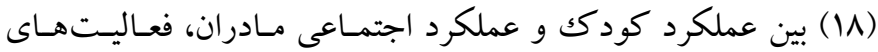

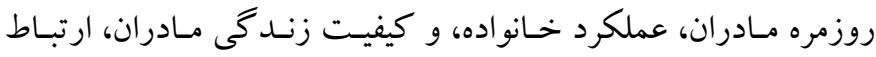




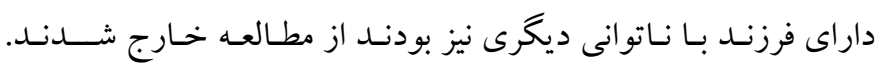

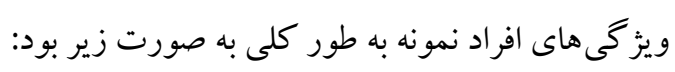

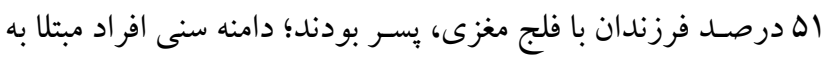

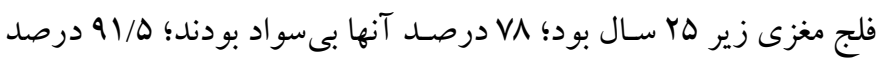
والدين كود كان با فلج مغزى، فرزند مبتلا به فلج مغزى ديخرى نداشـتـند

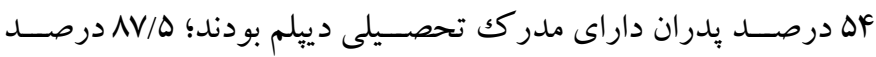

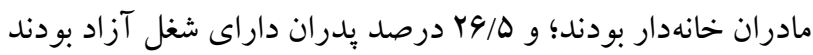

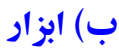
ا. يرسشنامه محقق ساخته سنجش نيازهاى والدين داراى كودكك مبتلا به

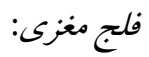
براى سـاخت اين يرسشنامه ابتدا به بررسى نظريهها و مطالعات انجام شده

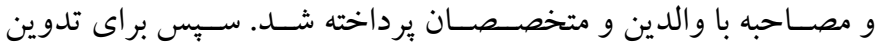

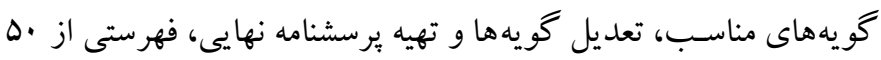

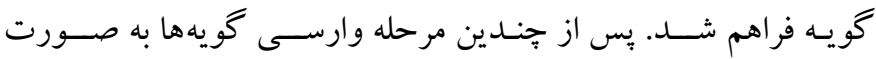

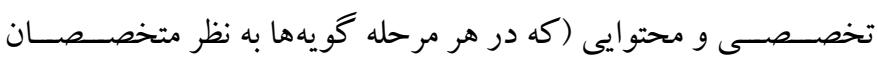

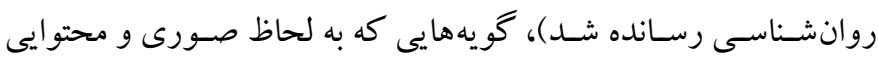

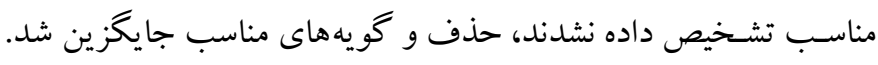

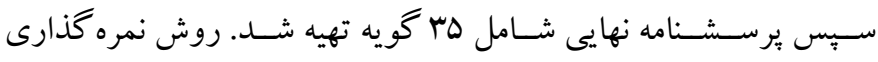

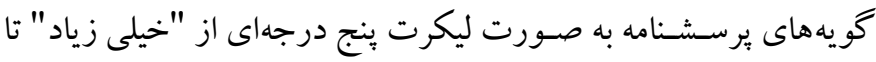

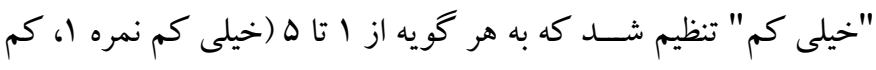

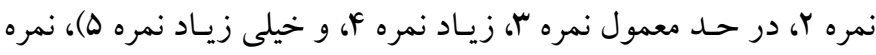
داده مى شد.

براى تعيين شـاخص هاى روانسـنجى برســــنامه از تحليل عاملى و

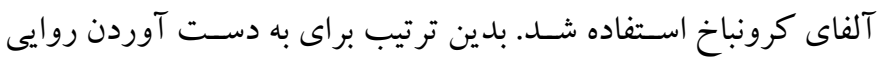

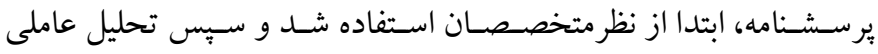

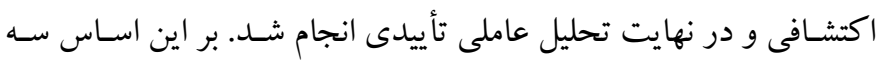
عامل به ترتيب زير شناسايى شد:

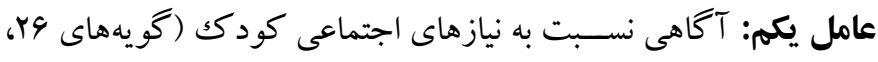

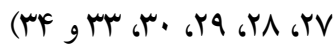
عامل دوم: آكاهى نسبت به نيازها و امكانات درمانى كود كك (كويههاى

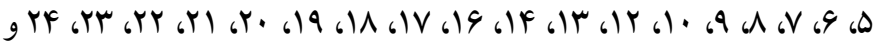

نيازهاى خود و فرزندشـان آكاهى داشــهـ باشــند، در فرايند برنامهريزى آموزشى و تو انبخشى فرزند خود مشاركت بيشترى مى كنند و در نتيجه

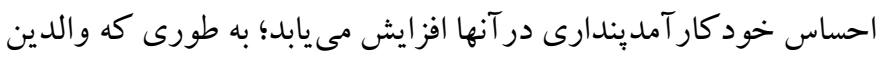

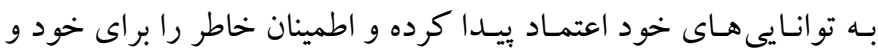
ديخر اعضاى خانو اده به ارمغان مى آورند. در اين ارتباط با توجه به اينكه

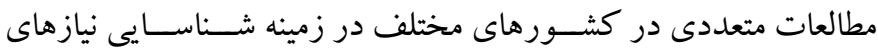
والدين كود كان با نياز هاى ويزه انجام شــــه اســت، ولى تاكنون مطالعه جامعى در ايران درباره شــناسـايى نيازهاى والدين كود كان مبتلا به فلج

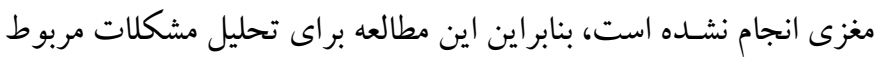
بــه افراد مبتلـا بـه فلج مغزى و بر آورد نيـازهاى واقعى والدين آنها، انجام شده است. بدين ترتيب يزوهش حاضر با هدف شناسايى و اولويتبندى نيازهاى والدين كود كان با فلج مغزى انجام شد. برد.

روش الف) طرح هزوهش و شر كت كنند عان: روش يزٔوهش حاضر توصيفى

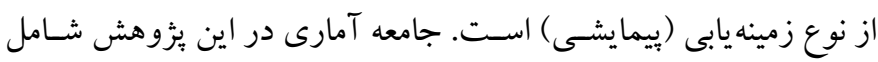

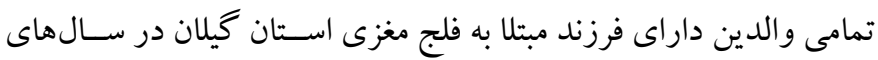

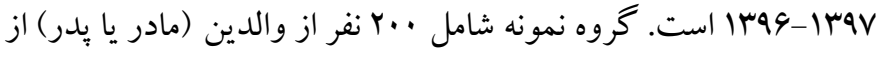
جامعه آمارى مذكور بودند كه با استفاده از روش نمونه كيرى هدفمند و بر حسب شــايط ورود و خروج از مطالعه، انتخاب شـــند. ملاكك تعيين

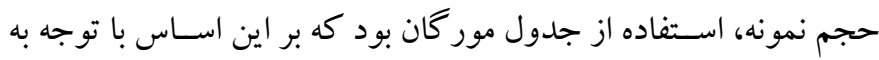

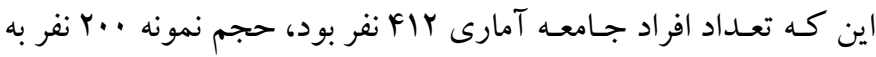

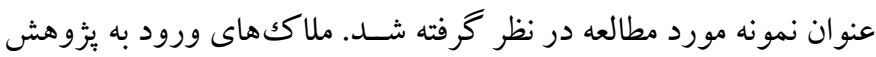
عبـارت بودنــد از: مشــخص بودن دقيق تشــخيص فلج مغزى فرزنــد در

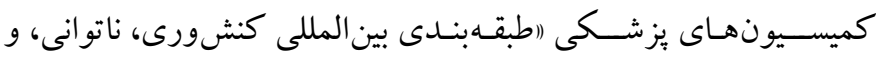
سلامت) با استفاده از ابزارهاى مربوطه و توسط متخصص مغز و و اعصاب،

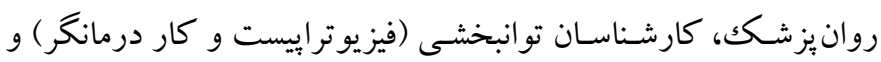

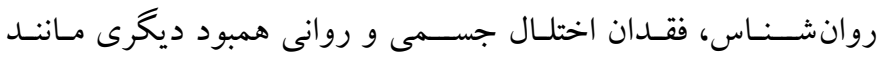

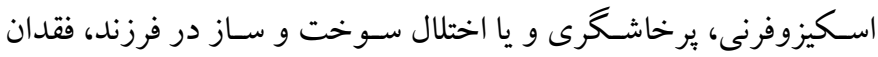

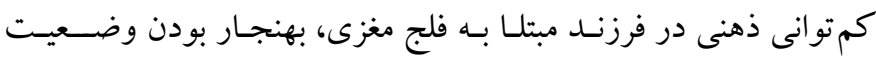

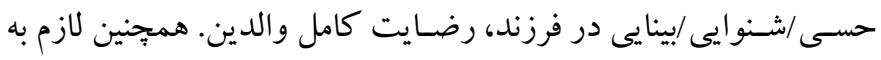

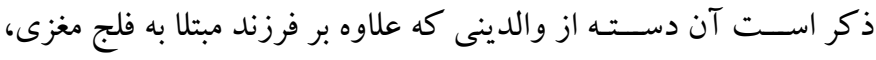


شهرستانهاى استان كيلان ارائه كردند. از طريق مكاتبه سازمانى، فهرست آمارى تمامى افراد فلج مغزى كه در ادارات بهزيستى شهرستانهاى استان

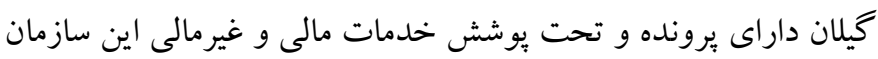
بودند، دريافت شده است و سبس والدين داراى فرزند مبتلا به فلج مغزى زير ها سال از كل جامعه آمارى، مورد شناسايى قرار گر فتند. بعد از تعيين و انتخاب افراد نمونه، به منظور تكميل دقيق و صحيح برسشنامها،

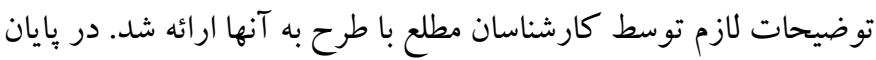
يرسشنامههاى اجرا شده، جمع آورى شده و تحليل دادهها انجام شد. للازم به ذكر است كه ملاحظات اخلاقى در اين مطالعه به طور كامل رعايت شد. بدين ترتيب به افر اد نمونه اطمينان داده شد كه اطلاعات شخصى آنان كاملاً محرمانه باقى مىماند و فقط كاربرد يُزوهشى دارد. همجِنين رضايت كامل

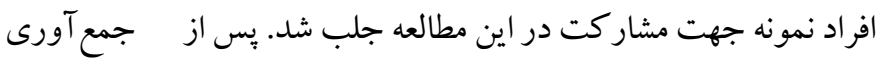

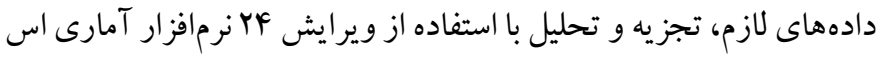

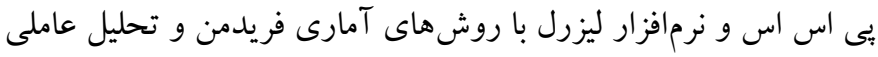
اكتشافى و تأييدى، انجام شد.

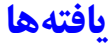

براى اولويت بندى نيازهاى والدين كود كان با فلج مغزى در سطح گويهها

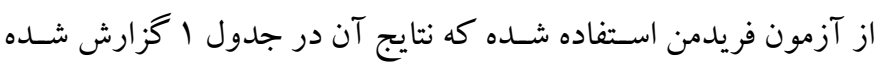

عامل سوم: نياز به دانش و آكاهى (كويههاى ا، Y، س، ال، ها و هr). براى سنجش روايى سازه يرسشنامه نيز از تحليل عامل تأييدى استفاده

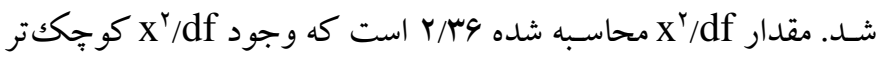
از rا، نشــاندهنـده برازش منـاســب مدل اســت. همجنين جذر بر آورد واريانس خطاى تقريب (RMSEA) بايد كمتر از ^•• باشد كه در مدل ارائه شــده اين مقدار برابر \& • ب بوده اسـت. ميز ان شــاخص هاى GFI، NFI و CFI ،AGFI بررسى به ترتيب بالاتر از ميزان تعيين شـده به دست آمد (يعنى به ترتيب

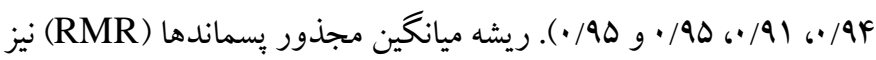
ץ./• به دست آمد كه كمتر از •ه/• است؛ بنابراين دادههاى اين يثزوهش

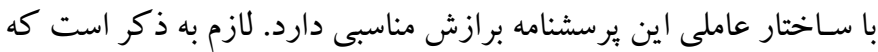

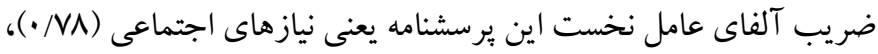

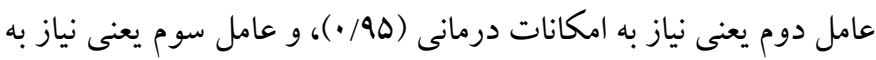

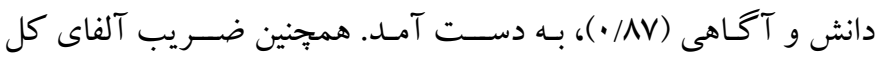

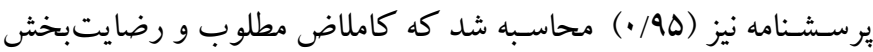

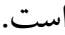
ج) روش اجرا: به منظور اجراى اين مطالعه، ابتدا با مراجعه به سازمان

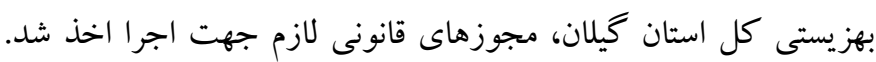
سبس در يك جلسه رسمى سازمان، يزوهشخر اطلاعات للازم را درباره اهداف و ضرورت انجام اين بثوهش به تمام كارشناسان ادارات بهزيستى

جدول ا: نتايج آزمون فريدمن مربوط به رتبهبندى تويههاى برسشنامه

\begin{tabular}{|c|c|c|}
\hline رتبه & ميانكين رتبه & تويه \\
\hline 1 & rY/KG & نغر انى نسبت به آينده شغلى و ازدواج فرزند \\
\hline r & $\mathrm{m} / \cdot \mathrm{q}$ & نغرانى نسبت به برخورد افراد جامعه با فرزند \\
\hline r & rQ/4Q & حمايت و تلاش اعضاى خانواده در جهت بهبود وضعيت فرزند \\
\hline r & re/Tr & ي ي يخيرى و انجام اقدامات درمانى به موقع و مورد نياز \\
\hline$\Delta$ & $r \Delta / v i$ & 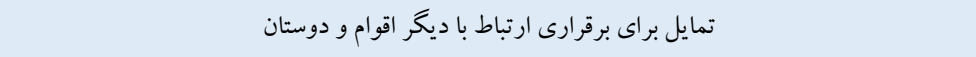 \\
\hline 4 & $r \mu / \& V$ & اطلاعات و امكانات خانو اده در مورد تغذيه و رزيم غذايى خاص به منظور كنترل مشكلات گو ارش \\
\hline$\checkmark$ & $r \cdot 194$ & انجام فعاليتهاى مفرح و شادى بخش در فضاى خانواده \\
\hline$\wedge$ & $19 / \Delta \Delta$ & 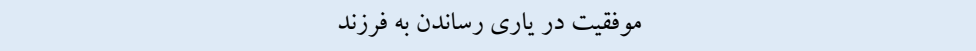 \\
\hline 9 & $|N / V|$ & بهرهمندى از حمايتهاى مر اقبتى بستگان در خصوص مديريت زمان براى رسيدگى به ديخر اعضاء خانو اده \\
\hline 1. & $1 / 190$ & زمان اختصاص يافته در طول هفته به خود \\
\hline 11 & IN/DY & بهرهمندى فرزند از امكانات و تجهيزات كمكك توانبخشى \\
\hline ir & IN/TV & 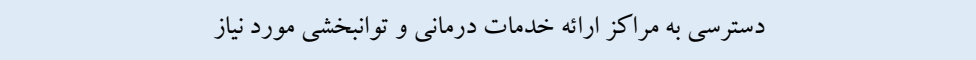 \\
\hline ir & IN/Yq & بهرهمندى از خدمات آموزشى و مشاورهاى خاص درباره كنترل مشكلات خواب \\
\hline
\end{tabular}




\begin{tabular}{|c|c|c|}
\hline If & $M \cdot \Delta$ & بهرهمندى از خدمات آموزشى و مشاورهاى خاص جهت ايجاد علاقه و انخيزه مشاركت در فرزند به منظور ياد گيرى \\
\hline 10 & $I V / \Delta \Delta$ & 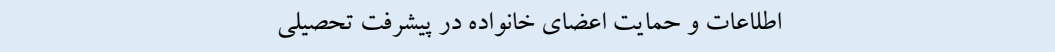 \\
\hline 19 & IV/TD & بهرهمندى از خدمات آموزشى و مشاورهاى خاص درباره جخگونخى مو اجهه با ناتوانىهاى حركتى و حسى \\
\hline IV & $1 \mathrm{~V} / 19$ & بهرهمندى از خدمات دولتى و خصوصى در زمينه كاهش مشكلات جسمى حر كتى \\
\hline M & $19 / \mathrm{Vr}$ & بهرهمندى از حمايتهاى آموزشى درباره واكنش درست در مواجهه با مشكل آفرينى فرزند براى ديخران \\
\hline 19 & $19 / \mu r$ & بهرهمندى از خدمات آموزشى و مشاورهاى خاص درباره نحوه ارتباط مؤثر با ديخر فرزندان \\
\hline r. & $19 / 1 \mathrm{r}$ & بهرهمندى از خدمات آموزشى و مشاورهاى خاص درباره مديريت هيجانها و راهكارهاى مقابله با تنيدگى \\
\hline r) & $19 / \cdot 4$ & بهرهمندى از خدمات مراكز آموزشى ويزه درباره كمكك به افزايش تو انايى كلامى و غير كلامى \\
\hline rr & $10 / 94$ & بهرهمندى از خدمات آموزشى و مشاورهاى ويزه مراكز درباره افزايش مهارتهاى بازى \\
\hline r & $10 / 9$. & بهرهمندى از خدمات دولتى و خصوصى درباره كاهش مشكلات ذهنى و يادگيرى \\
\hline YF & $10 / \cdot \Delta$ & بهرهمندى از خدمات دولتى و خصوصى درباره كاهش ساير مشكلات \\
\hline ro & $1 F / 94$ & بهرهمندى از خدمات آموزشى ويزه مراكز توانبخشى درباره افزايش هوش \\
\hline rq & $\mid F / V$ & اطلاعات والدين درباره مداخلات درمانى موجود براى اختلال فلج مغزى \\
\hline rV & $\mid F / \Delta r$ & رضايت از خدمات حمايتى جامعه و هميارى دولت در كمكك به مشكلات \\
\hline YA & $\mid f / \mu^{4}$ & 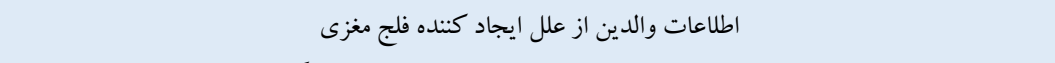 \\
\hline rq & $\mid f / r$. & بهرهمندى ازحمايتهاى آموزشى ويزه به منظور آموزش مهارتهاى زندگى و تعاملات اجتماعى \\
\hline r. & $\mid F / 14$ & بهرهمندى از امكانات و حمايتهاى مورد نياز در جهت كنترل مشكلات حر كتى و حسى در بيرون از خانه \\
\hline r & $\mid q / \cdot r$ & تاثير آموزش مهارتهاى انطباقى، مهارتهاى زندگى و تعاملات اجتماعى در بهبود عملكرد \\
\hline rr & $\mid r / F r$ & بهرهمندى از خدمات تو انبخشى خاص به منظور آموزش مهارتهاى انطباقى \\
\hline r & $|r / r|$ & بهرهمندى از حمايتهاى مراقبتى دولتى درباره مديريت زمان براى رسيدگى به ديخر اعضاء خانواده \\
\hline$\mu$ & $1 \cdot / \mathrm{VV}$ & تطابق هزينه درمان و آموزش ويزه فرزند مبتلا به فلج مغزى با توانايى مالى \\
\hline ro & $\Lambda / V V$ & بهرهمندى فرزند از امكانات و تجهيزات خاص در مدارس ويثه. \\
\hline & & آماره آزمون (آزمون فريدمن) \\
\hline سطح معنى دارى & درجه آزادى & آماره خى دو \\
\hline$\cdot / \cdot 1$ & $r F$ & $r r \cdot F / 9 \Lambda$ \\
\hline
\end{tabular}

مشـخص شــود والدين كود كان با فلج مغزى در كدام يكك از عاملهاى يرسـشــنامه نيازســنجى بيشـترين اهميت را قائل هســتند، تحليل رتبهاى فريدمن براى مقايسـه بين رتبه عامل هاى برسـشــامه صـورت گرفت كه نتايج آن در جدول r كزارش شده است.

جدول r: نتايج آزمون فريدمن مربوط به سه عامل برسشنامه

\begin{tabular}{|c|c|c|}
\hline رتبه & ميانكين رتبه & عامل \\
\hline 1 & $r$ & نياز به امكانات درمانى \\
\hline r & $1 / 94$ & نيازهاى اجتماعى \\
\hline$r$ & $1 / \pi q$ & نياز به دانش و آكاهى \\
\hline \multicolumn{3}{|c|}{ آماره آزمون (آزمون فريدمن) } \\
\hline سطح معنى دارى & درجه آزادى & آماره خى دو \\
\hline.$/ .1$ & r & \\
\hline
\end{tabular}

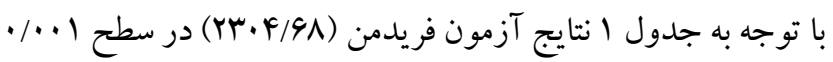
معنى دار اســت كـه نشــان مى دهـد حـداقـل يكى از ميـانگين رتبـههاى كويه هاى يرسـشــنامه بر ديخر ميانگين رتبه ها، ارحجيت دارد. با توجه به جدول ا، نكرانى نسـبت به آينده شـغلى و ازدواج فرزند با ميانگين رتبه

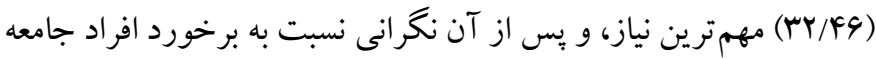
با فرزند با ميانگين رتبه (ه·/(M)، و حمايت و تلاش اعضـاى خانو اده در جهت بهبود وضعيت فرزند با ميانگين رتبه (Yq/\&4) در رتبه دوم و سوم قرار دارند. كماهميت ترين كويه ها نيز شـامل بهرهمندى فرزند ازامكانات و تجهيزات خـاص در مدارس ويثه با ميانكين رتبه (N/VV)، تطابق هزينه درمـان و آموزش ويثزه فرزنـد با توانايى مالى با ميانگين رتبه (l/NV)، و بهر همنـدى از حمـايـتـهـاى مراقبتى دولتى دربـاره مـديريست زمان براى

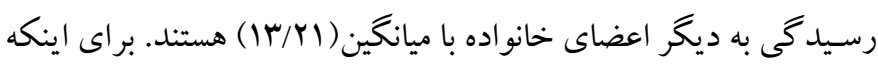


تحول است، به طورى كه مطالعات نشان مى دهند موانع نخرشى و محيطى

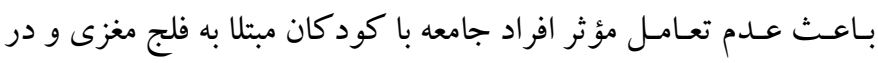

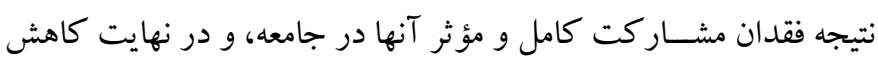

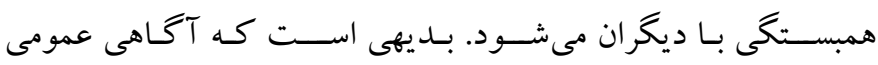
مر اقبت كنند كان و بالاخص افراد جامعه بر نيازهاى اجتماعى اين كود كان

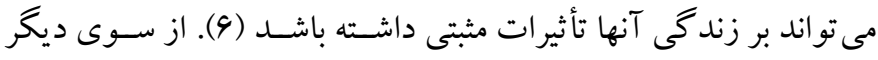

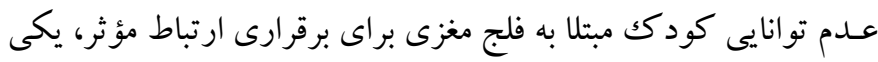

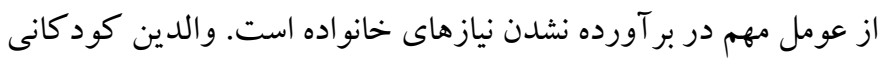
كه محدوديت هاى ارتباطى شديدترى دارند، به اطلاعات بيشتر و حمايت اجتماعى بيشـترى نياز دارند؛ به طورى كه آلماســرى و همكاران (Yr)

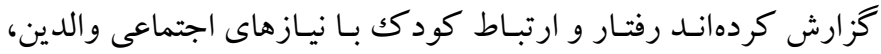

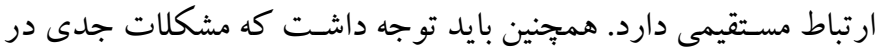

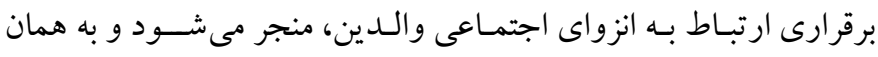
نسـبت والدينى كه قادر به درك نيازهاى فرزند خود نيسـتند، احســاس نـاراحتى و نـاميـدى بيشـترى كرده و ارتباط اجتماعى كمترى را برقرار

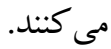
بـا توجـه بـه اينكـه نيـاز بــه امكانات درمانى جزء دومين نياز والدين

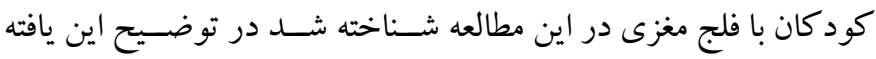

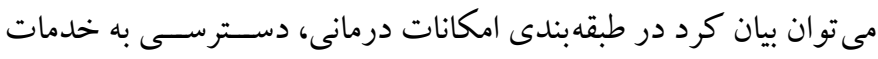

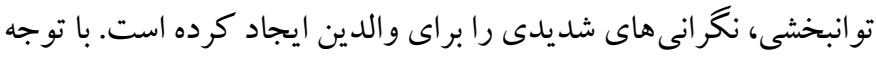

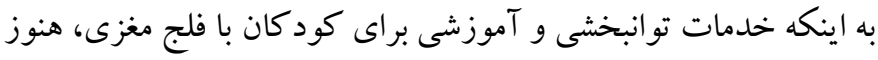

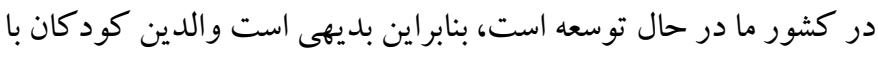

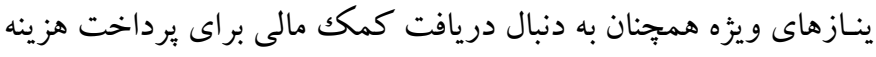

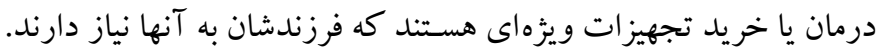

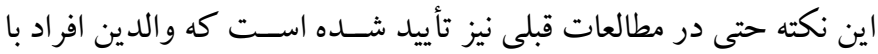
نـاتو انى در كشـــورهاى مختلف همجنان در تأمين خدمات آموزشـى و و

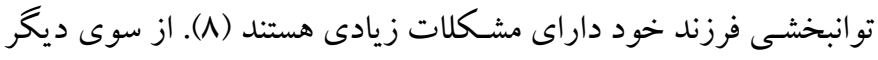

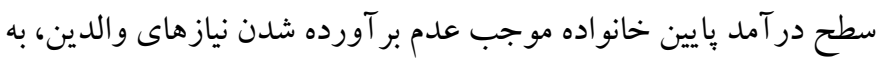
خصوص در زمينه امور مالى مىشود. در زمينه نيازهاى درمانى افراد مبتلا

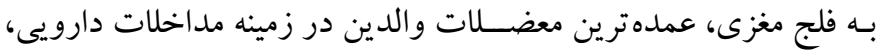

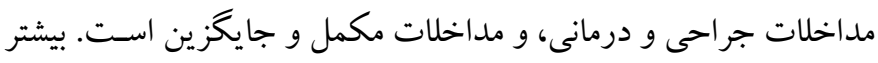

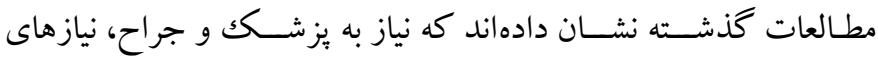

بـا توجـه بـه اطلاعات ارائه شـــده در جدول با، نتايج آزمون فريدمن

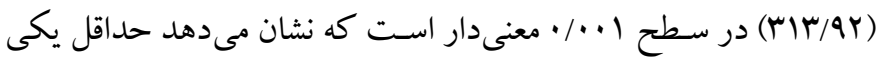

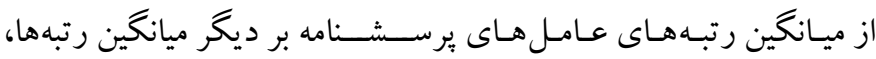
ارحجيـت دارد. بر اسـاس اين جدول، نياز به امكانات درمانى با ميانكين

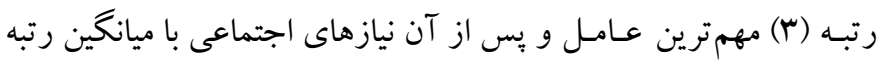

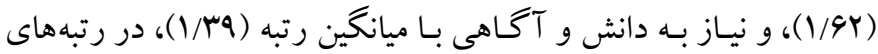
دوم و سوم قرار دارند.

\section{بحث و نتيجه تيرى}

يزؤهش حاضر با هدف شناسايى و اولويتبندى نيازهاى والدين كود كان

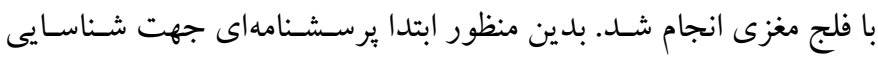
نيازهاى والدين اين كود كان سـاخته شد. براى مشخص كردن عاملهاى اين يرسـشــنامه از روش تحليل موازى و روش جرخش متمايل يرامين

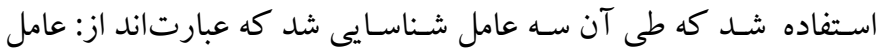
نيـازهـاى اجتماعى، عامل نياز به امكانات درمانى، و عامل نياز به دانش و و

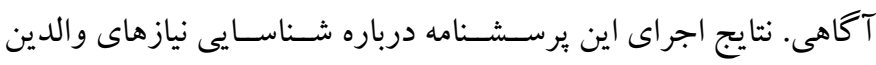
كود كان با فلج مغزى نشـان داد كه نياز به امكانات درمانى، مهم ترين نياز اين والدين اســت و يس از آن، نياز والدين در حيطه هاى اجتماعى و در نهايت نياز به كسب دانش و اطلاعات للازم، در رتبه هاى بعدى قرار دارند

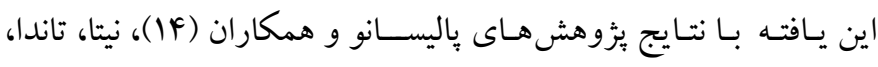

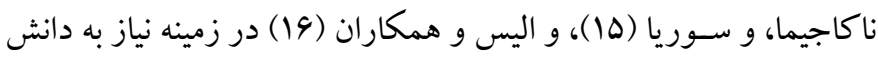

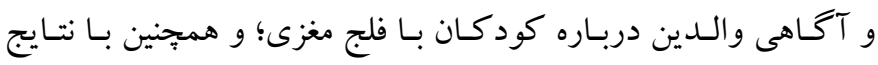

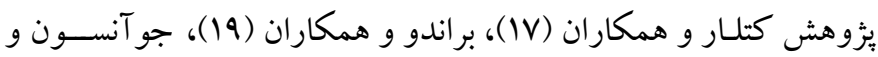

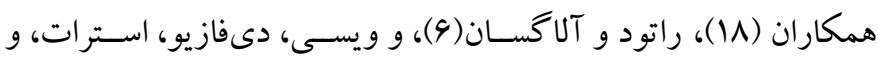
اسنايدر (ه) درباره نيازهاى اجتماعى و امكانات درمانى، همسو است. در تبيين يافته نخست اين مطالعه يعنى نيازهاى اجتماعى فرزند مبتلا به

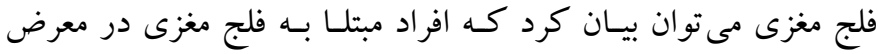
مشكلات فراخير اجتماعى در سراسر دنيا هستند كه اين مشكلات ممكن

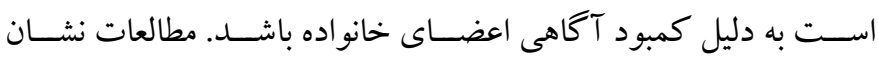
مى مهند فقدان شناخت بعضى از حقوق انسانى اين افر اد، عدم آكاهى در

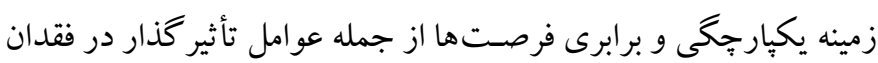

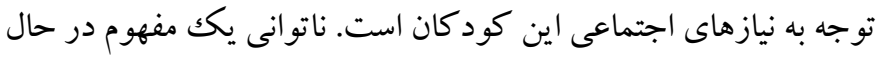


ارائه حمـايـتهـاى للازم و به موقع كمكك مى كند كه در نتيجه در فرايند

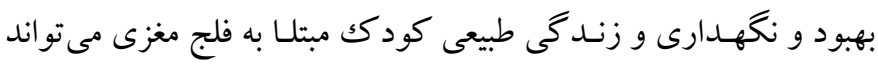

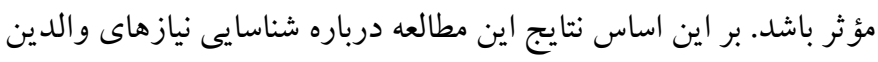

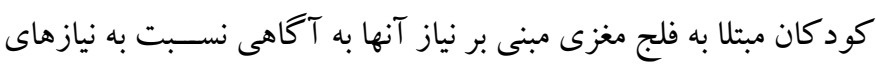

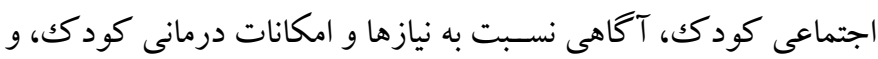

$$
\text { نياز به كسب دانش و آكاهى، منطقى به نظر مى رسد. }
$$

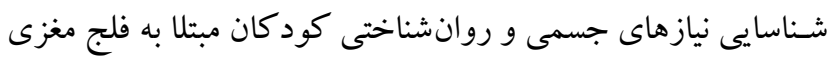

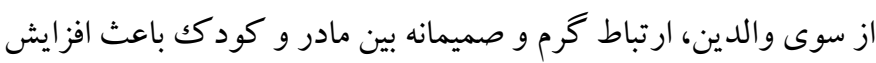

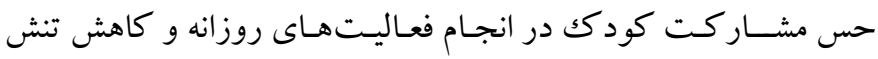
والدين مىشـود (سT). آموزش والدين داراى كود كك مبتلا به اختلال فلج مغزى باعث افزايش روابط مثبت بين بدر و مادر و كودكك مىشود و در

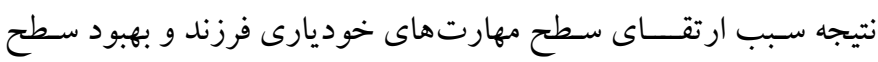

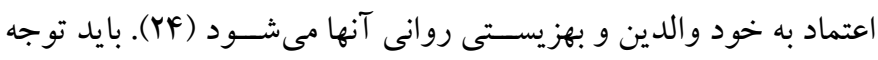

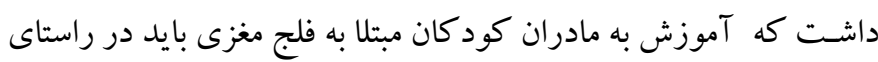

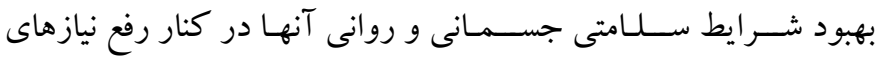

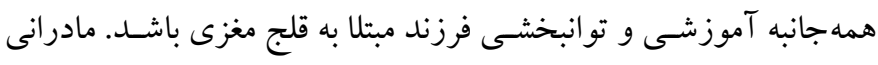

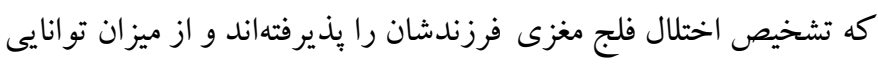
و ادراكات شناختى كودك خود آكاهى دارند، احساسات خود را كنترل

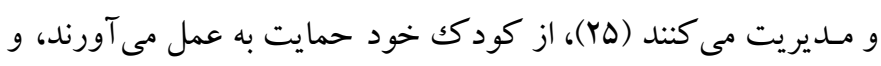

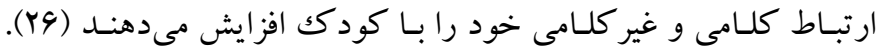

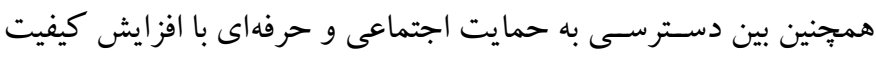

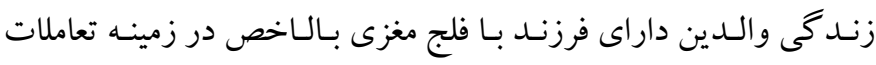

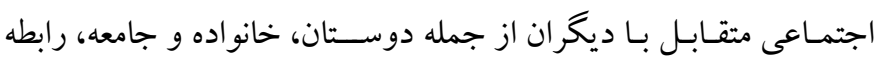
معنادارى وجود دارد؛ بنابراين بديهى اســت كه دســترسـى به به حمايت

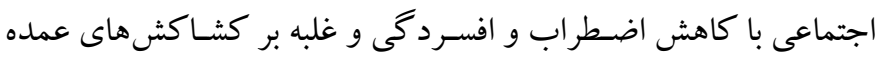
يدر و مادر در ارتباط با فرزند مبتلا به فلج مغزى، ارتباط قوى وجود دارد

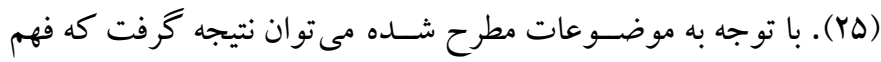

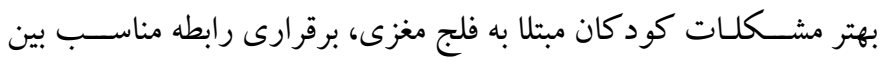

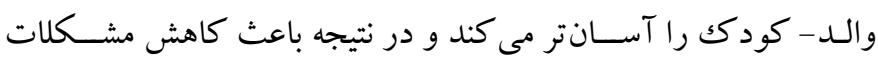
رفتارى كود كك و افزايش سـلامت روانى والدين مىشـود (سا). در اين راستا بايد توجه داشت كه نه تنها توجه به نيازهاى شناسايى شده والدين

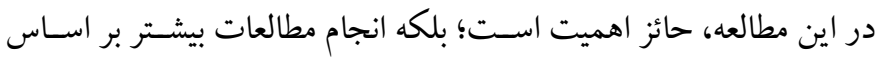

توانبخشى و كاردرمانى، فيزيوترايى، گفتاردرمانى، و وسايل و تجهيزات

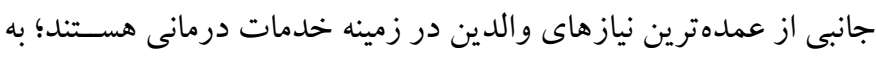

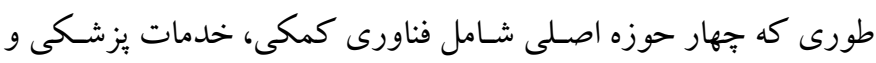
درمانى، حمل و نقل، و مشـاوره در اولويت نيازهاى درمانى والدين قرار

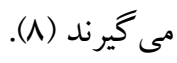
نتـايج اين يزوهش همجينين نشــان داد كه نياز به آكاهى و دانش در

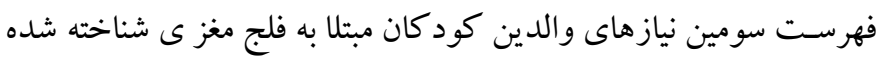

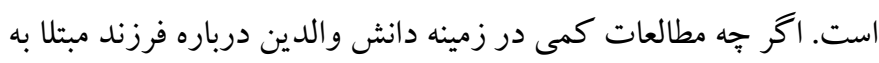
فلج مغزى وجود دارد، با اين حال مطالعه حاضــر نشــان داد كه بيشـتر والدين اين كودكان، اطلاعات كافى در زمينه نيازهاى اساسى فرزند خود

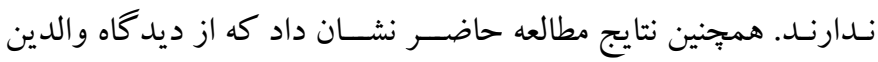

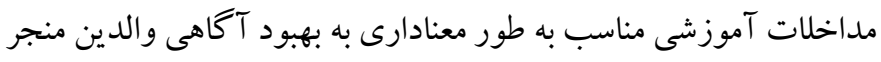

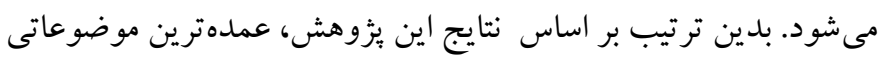

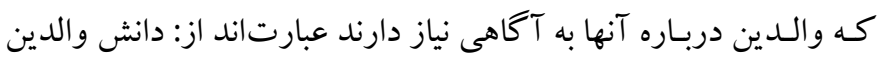

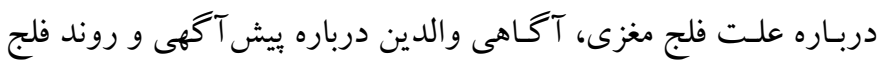

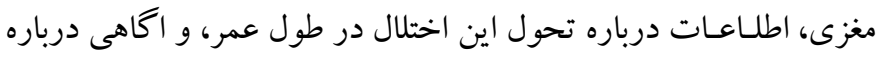

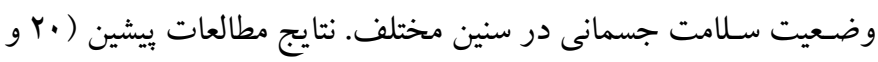

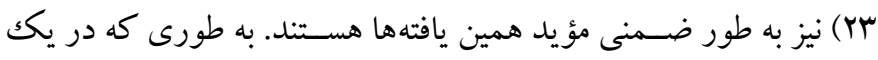

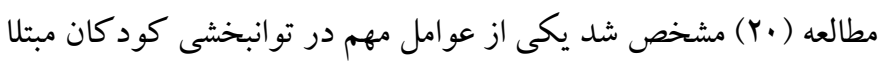
به فلج مغزى، مشـار كت فعال والدين در اين زمينه اسـت و آكاهى مؤثر والدين نـه تنها باعث بذيرش بهتر اين اختلال مى شــود، كه به شــروع

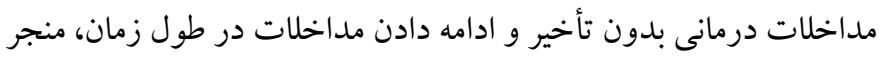
مىشود. بايد توجه داشــت كه والدين داراى فرزند مبتلا به اختلال فلج مغزى

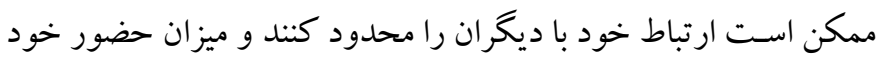

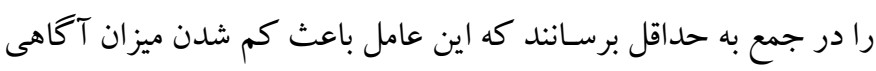

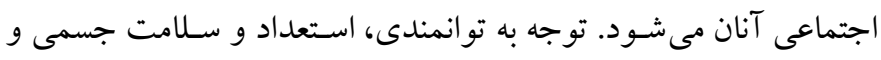

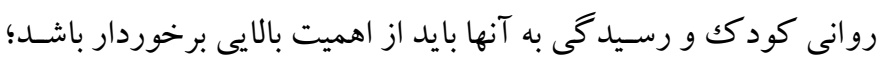
بنـابر اين نقش والـدين در روند مراقبت و تو انبخشـى اين كود كان كاملاً تخصصى و قابل توجه اسـت. داشـتن درك درست و واقعى از نيازهاى

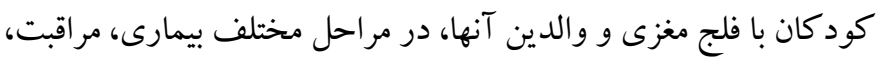

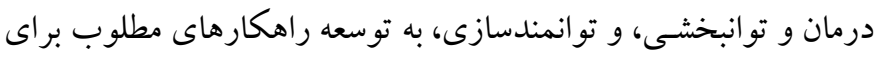


احتياط عمل كرد. در بايان ييشـنهاد مىشـود از نتايج مطالعه حاضــر در

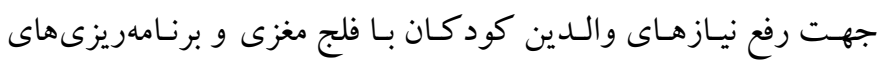

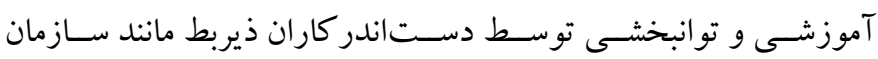

$$
\text { بهزيستى استان گيلان، استفاده شود. }
$$

تشكر و قدردانى: اين يزوهش بر كرفته از بايانامه كارشـناسى ارشد مطهره

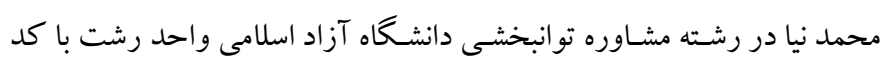

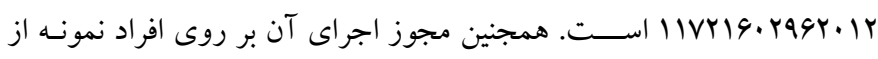

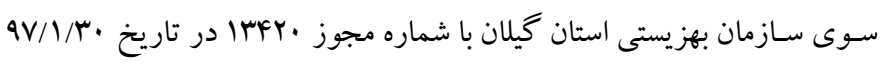

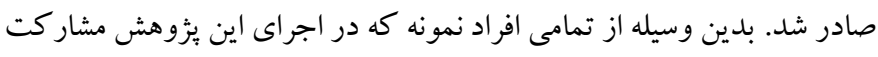

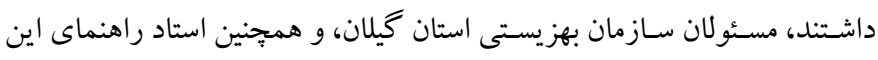
مطالعه، تشكر و قدردانى مىشود. تضـاد منافع: اين بثزوهش هيج گونه تضـاد منافعى براى نويسـند كان به همراه نداشته است.
يافتهاى به دست آمده مى تواند راهگشاى مسئولان و دستاندر كاران در

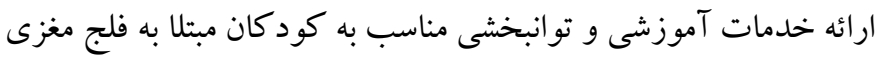

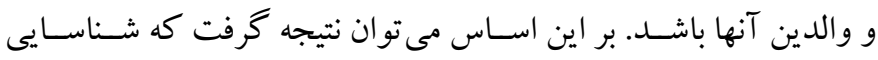

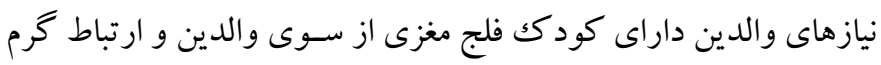

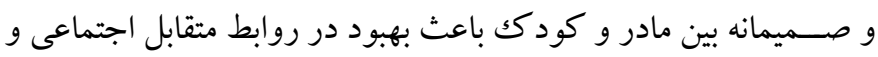
كاهش رفتارهاى سازشنايافته در كودك مى در اين يزوهش به علت مشـكلات اجرايى و فقدان دسترسى به حجم

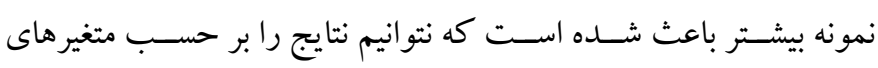
جمعيتشـناختى مختلف مانند سـن، جنس، و تحصـيلات والدين انجام

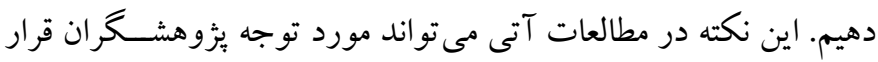

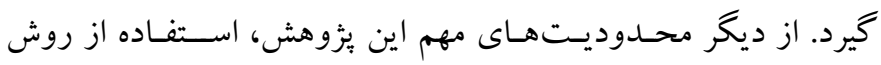

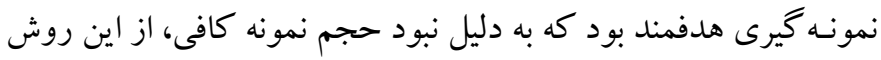

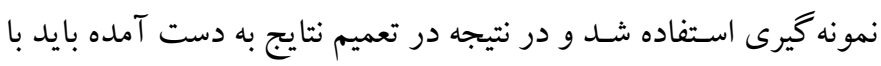




\section{References}

1. Heskett J. What's the best way to make careful decisions? [Internet]. HBS Working Knowledge [Serial Online] 04 Feb 2010. [Cited 2020 Jun 6]. Available from: [Link]

2. Wyne AH, Al-Hammad NS, Splieth CH. Oral health comprehension in parents of Saudi cerebral palsy children. Saudi Dent J. 2017; 29(4): 156-160. [Link]

3. Centers for Disease Control and Prevention. Data and statistics for cerebral palsy [Internet]. CDC [Serial Online] 2020. [Cited 2020 Jun 6]. Available from: [Link]

4. Longo E, Badia M, Begoña Orgaz M, Gómez-Vela M. Comparing parent and child reports of health-related quality of life and their relationship with leisure participation in children and adolescents with Cerebral Palsy. Res Dev Disabil. 2017; 71: 214-222. [Link]

5. Vessey JA, DiFazio RL, Strout TD, Snyder BD. Impact of non-medical out-of-pocket expenses on families of children with cerebral palsy following orthopedic surgery. J Pediatr Nurs. 2017; 37: 101107. [Link]

6. Rathod VJ, Alagesan J. Family awareness on legislative issues on child with cerebral palsy: Cross sectional survey. International Journal of Physiotherapy and Research. 2014; 2(3): 511-517. [Link]

7. Badia M, Begoña Orgaz M, Gómez-Vela M, Verdugo MA, Ullán AM, Longo E. Do environmental barriers affect the parent-reported quality of life of children and adolescents with cerebral palsy? Res Dev Disabil. 2016; 49-50: 312-321. [Link]

8. Bertule D, Vetra A. Predictors of needs for community and financial resources for families of pre-school children with cerebral palsy. SHS Web of Conferences. 2016; 30: 00041. [Link]

9. Glasscock R. A phenomenological study of the experience of being a mother of a child with cerebral palsy. Pediatr Nurs. 2000; 26(4): 407-410. [Link]

10. Rosenbaum P, Paneth N, Leviton A, Goldstein M, Bax M, Damiano D, et al. A report: The definition and classification of cerebral palsy April 2006. Dev Med Child Neurol Suppl. 2007; 109: 8-14. [Link]

11. Krstić T, Mihić L, Mihić I. Stress and resolution in mothers of children with cerebral palsy. Res Dev Disabil. 2015; 47: 135-143. [Link]

12. World Health Organization. International classification of functioning, disability, and health:
Children \& youth version: ICF-CY. World Health Organization; 2007. [Link]

13. Vickers NJ. Animal communication: When I'm calling you, will you answer too? Curr Biol. 2017; 27(14): 713-715. [Link]

14. Palisano RJ, Almarsi N, Chiarello LA, Orlin MN, Bagley A, Maggs J. Family needs of parents of children and youth with cerebral palsy. Child Care Health Dev. 2010; 36(1): 85-92. [Link]

15. Nitta O, Taneda A, Nakajima K, Surya J. The relationship between the disabilities of school-aged children with cerebral palsy and their family needs. J Phys Ther Sci. 2005; 17(2): 103-107. [Link]

16. Ellis JT, Luiselli JK, Amirault D, Byrne S, O’MalleyCannon B, Taras M, et al. Families of children with developmental disabilities: Assessment and comparison of self-reported needs in relation to situational variables. J Dev Phys Disabil. 2002; 14(2): 191-202. [Link]

17. Ketelaar M, Vermeer A, Hart H, van Petegem-van Beek E, Helders PJ. Effects of a functional therapy program on motor abilities of children with cerebral palsy. Phys Ther. 2001; 81(9): 1534-1545. [Link]

18. Johnson A, Gambrah-Sampaney C, Khurana E, Baier J, Baranov E, Monokwane B, et al. Risk factors for malnutrition among children with cerebral palsy in Botswana. Pediatr Neurol. 2017; 70: 50-55. [Link]

19. Brandão MB, Oliveira RHS, Mancini MC. Functional priorities reported by parents of children with cerebral palsy: Contribution to the pediatric rehabilitation process. Braz J Phys Ther. 2014; 18(6): 563-571. [Link]

20. Guyard A, Michelsen SI, Arnaud C, Fauconnier J. Family adaptation to cerebral palsy in adolescents: A European multicenter study. Res Dev Disabil. 2017; 61: 138-150. [Link]

21. Bertule D, Vetra A. The family needs of parents of preschool children with cerebral palsy: The impact of child's gross motor and communications functions. Medicina (Kaunas). 2014; 50(6): 323-328. [Link]

22. Almasri NA, Palisano RJ, Dunst CJ, Chiarello LA, O'Neil ME, Polansky M. Determinants of needs of families of children and youth with cerebral palsy. Child Health Care. 2011; 40(2): 130-154. [Link]

23. Castilho ARF de, Mialhe FL, Barbosa T de S, PuppinRontani RM. Influence of family environment on children's oral health: A systematic review. J Pediatr (Rio J). 2013; 89(2): 116-123. [Link]

24. Yilmaz H, Erkin G, İzki AA. Quality of life in mothers of children with cerebral palsy. ISRN Rehabilitation. 2013; ID 914738: 1-5. [Link] 
25. Almasri NA, O’Neil M, Palisano RJ. Predictors of needs for families of children with cerebral palsy. Disabil Rehabil. 2014; 36(3): 210-219. [Link]
26. Masood A, Arshad R, Mazahir S. Families of children with cerebral palsy: Family functioning domains. International Journal of School and Cognitive Psychology. 2015; 2(1): 1-6. [Link] 